\title{
Charles Peirce and Cuba
}

\section{Rosa Maria Mayorga}

\section{OpenEdition}

\section{Journals}

Electronic version

URL: http://journals.openedition.org/ejpap/306

DOI: 10.4000/ejpap.306

ISSN: 2036-4091

\section{Publisher}

Associazione Pragma

\section{Electronic reference}

Rosa Maria Mayorga, "Charles Peirce and Cuba », European Journal of Pragmatism and American Philosophy [Online], VI-2 | 2014, Online since 24 December 2014, connection on 19 April 2019. URL: http://journals.openedition.org/ejpap/306 ; DOI : 10.4000/ejpap.306

This text was automatically generated on 19 April 2019

\section{(c) (i) $\odot$}

Author retains copyright and grants the European Journal of Pragmatism and American Philosophy right of first publication with the work simultaneously licensed under a Creative Commons AttributionNonCommercial-NoDerivatives 4.0 International License. 


\title{
Charles Peirce and Cuba
}

\author{
Rosa Maria Mayorga
}

\section{AUTHOR'S NOTE}

This essay is part of the symposium on "The Reception of Peirce in the World" appeared in the last issue of EJPAP, 6, 1. A version of this paper was presented at the Charles S. Peirce International Centennial Congress in Lowell, Massachusetts, on July 2014.

1 Only a fragment survives of the letter Charles Peirce wrote to his mother in early 1885, while stationed in the small island of Key West, Florida, the southernmost point of the United States, on Coast Survey business. As far as we know, neither he nor his wife Juliet (te) ever made it to Havana, located just 90 miles south of Key West. However, although he likely never set foot in Cuba, there are some interesting connections with Peirce, pragmatism, and Cuba that I have come upon in the last few years, and which are the subject of this paper.

2 It was during the first Atlantic Coast Pragmatist Conference at the University of Virginia in 2006, that the late Michael Eldridge, admirer of Dewey, inadvertently put me on a trail of research which I have pursued, more off than on, in the years hence. Michael Eldridge did not speak Spanish, and upon learning that I did, offered to give me a copy of a book on pragmatism he had received as a gift from a Cuban author he had met while attending a conference in Cuba the previous year. This was the beginning of my research into the connections, both historical and philosophical, with Peirce and Cuba, undertaken since that fateful meeting at UVA, an interest which has subsequently taken me to Indianapolis, Boston, and Key West in search of information. ${ }^{2}$ I will start out with the historical, and end with some brief thoughts on some of the philosophical connections. 


\section{Peirce and Spaniards}

3 Charles Peirce is not known for his political engagement. In his personal letters, for instance, he mentions a momentous event such as the Civil War (the War between the States) only once - the fact that he dreaded being drafted - while his maiden aunt, as well as other relatives, expressed their political opinions about the subject freely in their correspondence (Brent 1993: 61-66). That is why his comments regarding U.S. involvement in the Cuban independence movement from Spain in a draft of a letter probably written sometime in 1898 to his cousin, the famous Massachusetts politician Henry Cabot Lodge, are especially striking:

I have from boyhood been taught by Massachusetts statesmen that the U. S. should possess Cuba. I don't believe the Spaniards will make a good fight; for as I have studied them in Spain, the whole people have been corrupted with the centuries of cruelty, injustice and rapine they have indulged in, and they have little manhood left. (L 254)

\section{Letter from Peirce to Henry Cabot Lodge, 1898}

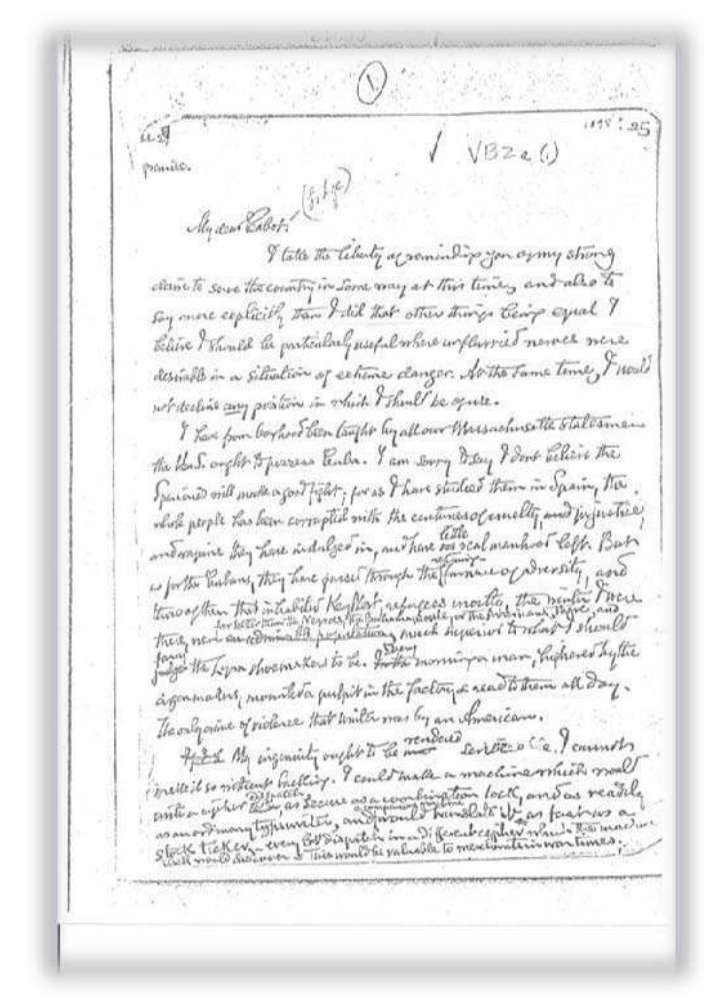

4 In a letter written to his brother James (Jem) that same year, Peirce expresses the same negative sentiment about Spaniards, adding "treachery" to the list of unfortunate Spanish traits. He further writes:

I am entirely in favor of the war. Two years ago I thought the United States instead of recognizing Cuba for which there was no justification, should have intervened in the name of civilization. Besides, I have always thought we wanted Cuba. (L 254) 


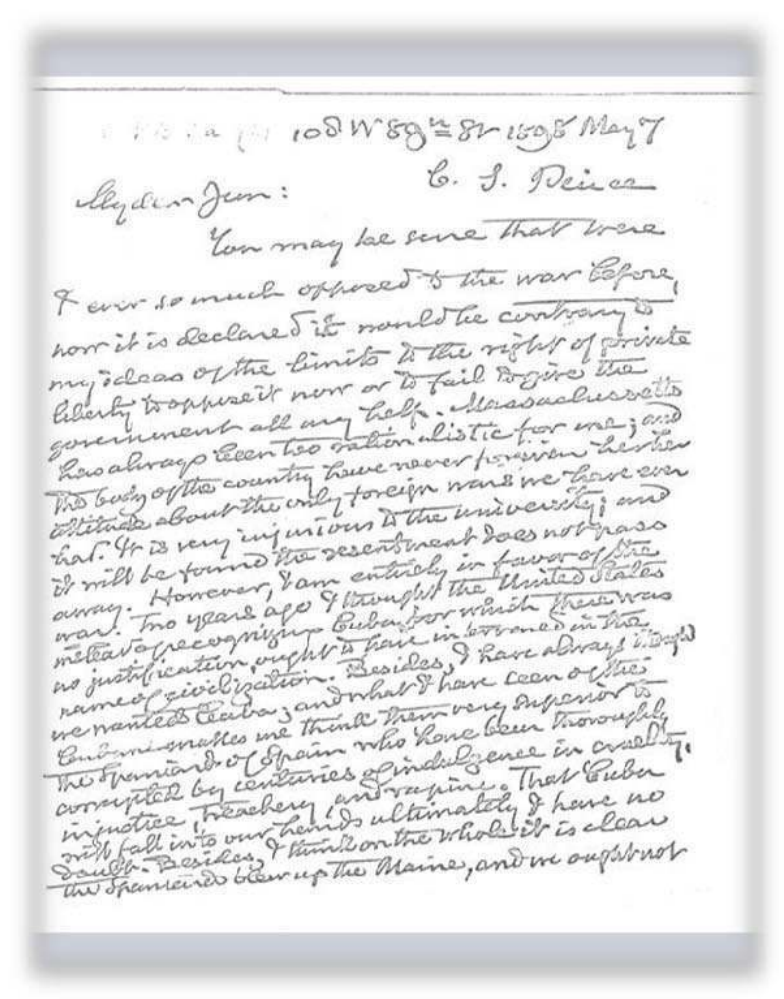

The war to which Peirce refers, of course, is the Spanish American War, declared by the U.S. against Spain in 1898 as a result of the explosion on the American ship, the Maine, stationed off the coast of Havana. The Spaniards were defeated, and Cuba acquired independence from Spain as a result. It is interesting that besides the fact that Peirce comments on a current event, his opinion about Spaniards is so negative. Obviously, one would expect that the enemy is seen that way during times of war, and indeed many fellow Americans had such a view, but Peirce seems to have held

that opinion from years before. Jaime Nubiola, who has written on Peirce and the Hispanic world, proposes that another reason for the negativity is the rivalry between both countries for commercial control of the Caribbean, as well as to Juliette's undue influence, who, as many French people of the time, Nubiola tells us, harbored deep antiSpanish sentiments (Nubiola 2006). The fact that Peirce's wallet was stolen while he was stationed in Spain for the U. S. Coast Survey does not help matters much either, I think.

\section{Spain and the U.S.}

7 It would not be unreasonable, then, to cite the politics and economics of the times as at least part of the reason for this negativity towards Spaniards and their descendants. The three-month long Spanish- American War which erupted after the Maine sank in Havana Harbor was the last chapter in a long series of hostilities. The old rivalries between Spain and England were mirrored in the New World as soon as the English arrived in the continent almost 60 years after the Spanish; there was espionage, piracy by both sides, skirmishes, in short, all manner of antagonisms. Relations between Spain and the new nation of the United States continued mostly along the same path; in the early 1800s, 
when pirates set up shop in the village of Regla in Havana's harbor to resell the plunder of U.S. ships, the first of many deployments of U.S. Marines landed along the Cuban coast (Larrua-Guedes 2010: 21).

Both Spain and the U.S. were well aware of the strategic location and the riches of the island; since Christopher Columbus landed in Cuba in 1492, it became one of the most important administrative centers of the Spanish colonies as well. Florida was named by Ponce de Leon when he first landed there from an expedition that started from Cuba in 1513. Other expeditions which resulted in the exploration of Mexico, Central and South America, as well as a major part of North America embarked from Cuba as well. In 1524 Spanish ships reached as far north as Canada; by 1535 , the Spaniards had reached the Rio de La Plata in South America. St. Augustine, Florida, the oldest city in the U.S., was founded by the Spaniards in 1565 (Larrua-Guedes 2010: 31).

\section{Map of Southern U.S. and Cuba}

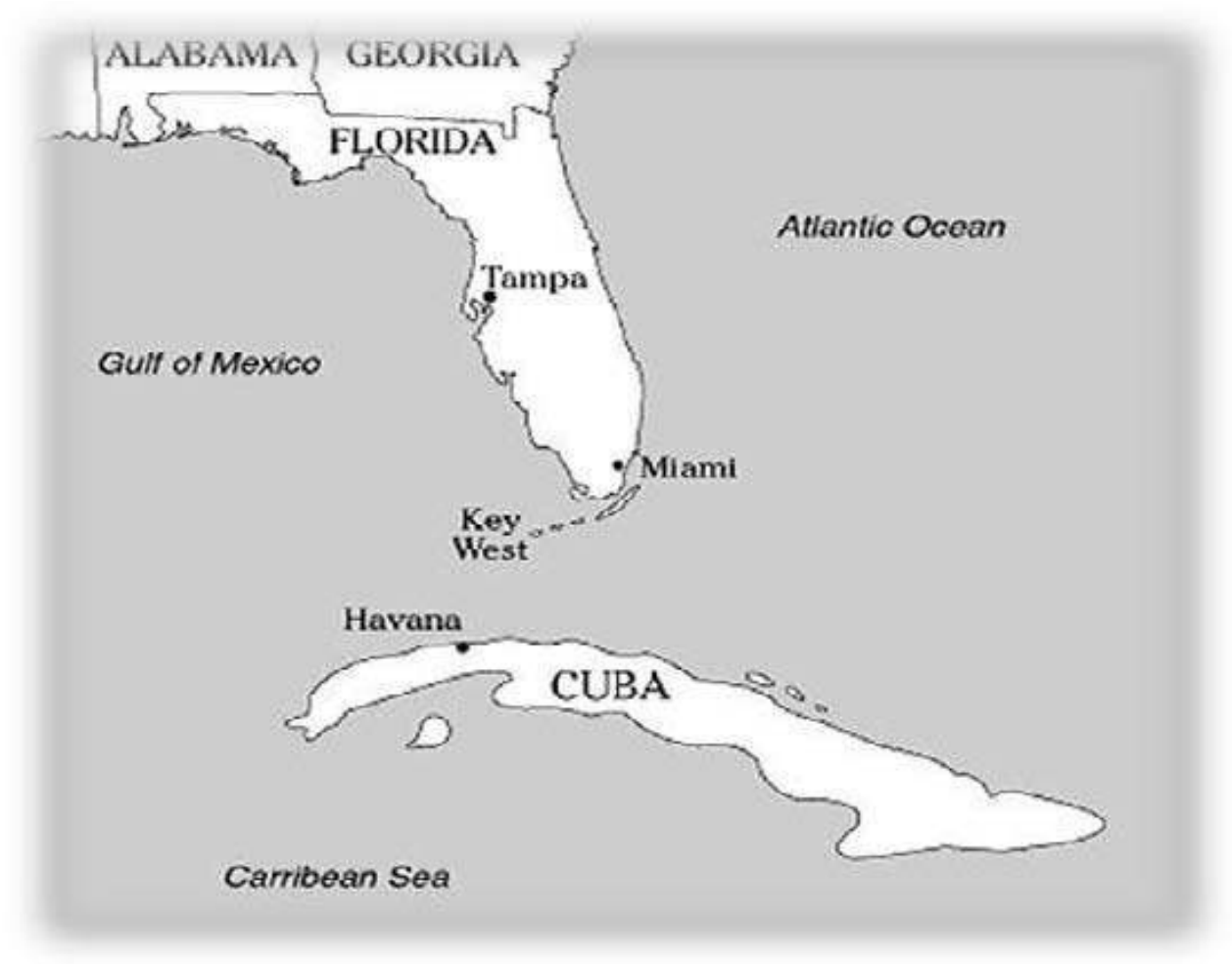

John Quincy Adams and Thomas Jefferson both were aware of the importance of Cuba; Adams wrote that Cuba and Puerto Rico were "natural appendages of the North American continent" (Schoultz 2009). An aging Thomas Jefferson expressed the same sentiment to then-President James Monroe - Cuba's "addition to our confederacy is exactly what is wanting to round out our power as a nation" (Schoultz 2009). A few months later, he wrote:

I have ever looked on Cuba as the most interesting addition which ever be made to our system of States. The control which, with Florida Point, this island would give us over the Gulf of Mexico, and the countries and isthmus bordering on it, as well as those whose waters flow into it, would fill up the measure of our political wellbeing. (Schoultz 2009: 7) 


\section{resources. The fertile soil produced by that time a considerable portion of the world's} supply of sugar, and whoever controlled it could control the world market.

11 generations officially respected Spanish sovereignty, though there were individuals who directly supported the Cuban separatists. When the 10-years unsuccessful struggle for Cuban independence broke out in 1868 , just as the American Civil War came to a close, some members of Congress again saw an opportunity for annexation of the island. But others were very much opposed to annexation - many argued against "a further introduction of the African element", against making American citizens "of the naked natives of the tropics", and that "we have enough of inferior races in our midst without...the Creoles and blacks of Cuba" (Schoultz 2009: 20-23).

Meanwhile, Spain made some conciliatory reforms, but nevertheless the insurgency continued, and Cuban businessmen and intellectuals traveled to the U.S., asking for support. Based in New York, the Cuban Revolutionary Party formed important relations with newspapers, which had daily coverage of the rebellion; public opinion began to be swayed, and sympathy for the insurgents grew. When Consul-General Fitzhugh Lee reported that mobs, led by Spanish officers, were creating mayhem in Havana's streets and sent a message that "ships must be sent", President McKinley's response was to move the battleship Maine to Havana Harbor, where it sat at anchor until the night of February 15, 1898, when an explosion tore open the ship's hull, sinking it, and killing 260 U.S. sailors (Schoultz 2009: 20-23). Although the U.S. declared war as a result, today it is considered that the explosion was likely not the result of sabotage by the Spanish. By December, the last Spanish troops left the island; U.S. troops arrived in their place. In 1902, the U.S. officially handed control to a Cuban government. ${ }^{3}$

\section{Peirce and Cubans}

13 It comes rather as a surprise to discover that Peirce, who had such a low opinion of Spaniards, at the same time seemed to hold Cubans, many of whom were direct descendants of Spaniards, in high regard. In the same letters where he maligns the former, he praises the latter:

But as for the Cubans, they have passed through the refining furnace of adversity, and those of them that inhabited Key West, refugees mostly, the winter I were there, were far better than the Negroes, the Bahama people, or the Americans there, and much superior to what I should fancy the Lynn shoemakers to be.

$[\ldots .$.$] and what I have seen of the Cubans makes me think them very superior to the$ Spaniards. (L 254)

Peirce's opinion of Cubans, however, was in marked contrast to the opinion of many of his American contemporaries, who saw Cubans in the same unfavorable light as they did Spaniards:

Many of them possess the superficial charm of clever children, spoiled by nature and geography - but under the surface they combine the worst characteristics of the unfortunate admixture and interpenetration of Spanish and Negro cultures - of laziness, cruelty, inconstancy, irresponsibility, and inbred dishonesty...[they are] generally of little good, and no more capable of self government than the savages of Africa. The average Cuban is of a very low order of mankind...[a] mixture of 
Spanish, Indian, Italian, and negro, and he inherits the bad qualities of all. (Schoultz 2009: 7)

formed his favorable opinion of Cubans when he came into contact with the Cuban community in early 1885 when he was stationed in Key West for his work on the U.S. Coast and Geodetic Survey. ${ }^{4}$ The previous year, in a letter to J. E. Hilgard, Superintendent of the Coast Survey, he had recommended that future gravity measurements be taken and stations set up "where there is geographical and geological diversity" (W: 5.144-49, 1884). Peirce provided Hilgard with a list of 114 stations (past and proposed) ranging from Reikjiavik to Patagonia, Sydney to Halifax.

\section{List of proposed gravity stations}

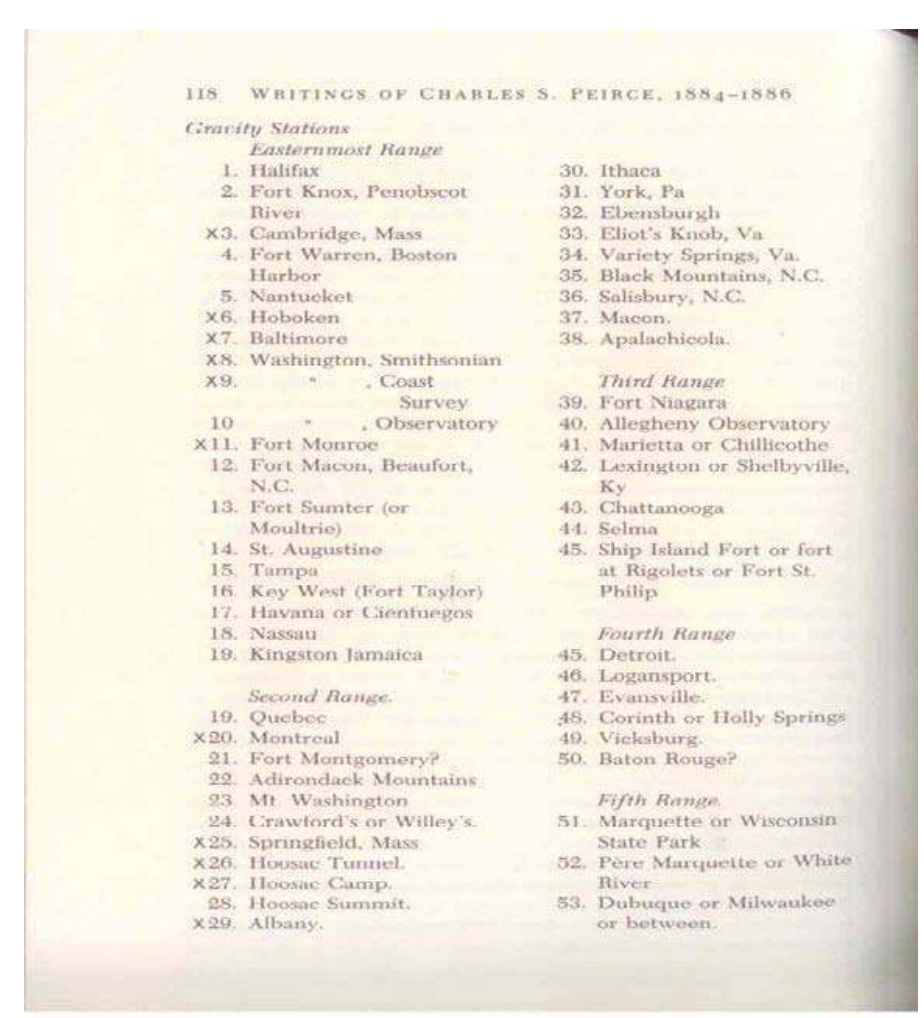

Included in this list, in addition to Fort Taylor in Key West, the Cuban cities of Havana and Cienfuegos are listed (W: 5.144-49). Perhaps if circumstances had been different (during this time the Coast Survey was in the midst of an investigation for mismanagement and as a result many scientific investigations were eventually curtailed) Peirce might have traveled at some point to Cuba to continue the gravity measurements there.

\section{Peirce and Key West}

17 It made sense for Peirce to begin the planned Caribbean investigations in Key West. At that time, Key West was the largest city in Florida, with 18.000 inhabitants. Before becoming part of U.S. territory in 1821, Key West was mostly occupied by Bahamians, who engaged in the lucrative wrecking trade (there was a fine line between wrecking and piracy; in the former, you were bound to save lives before salvaging and auctioning the 
remains of wrecked ships crashing into the Great Barrier Reef in front of the island). By early 1831, two lighthouses were built, and the U.S. Army Barracks was officially established at Fort Taylor, Key West.

\section{Map of Key West, Florida}

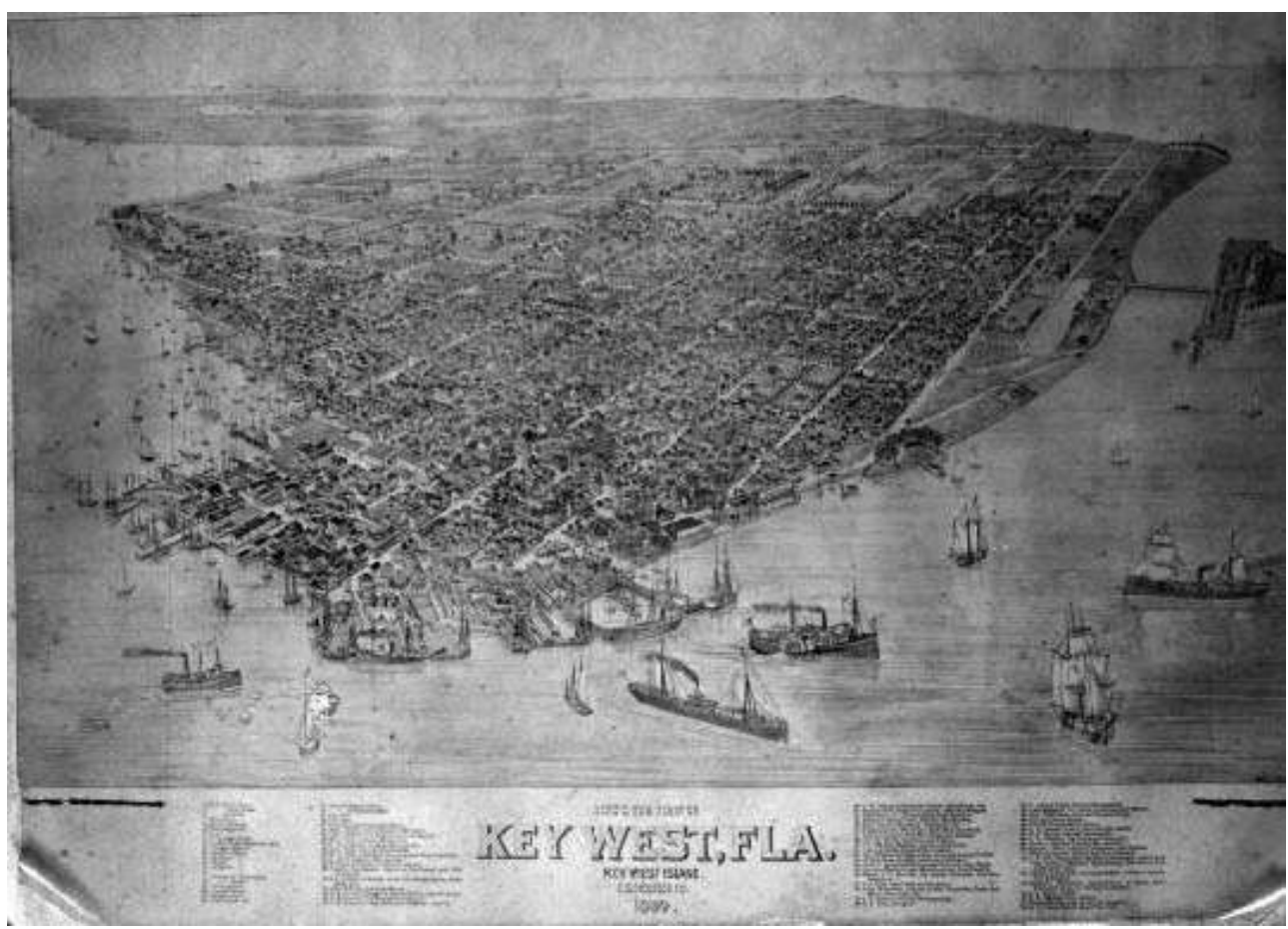

PHOTOgRAPHS OF KEY WEST, UNLESS OTHERWISE NOTED, ARE FROM THE MONROE COUNTY PUBLIC LIBRARY HTTP://BIT.LY/KEYSPIC.

\section{Fort Taylor, Key West}

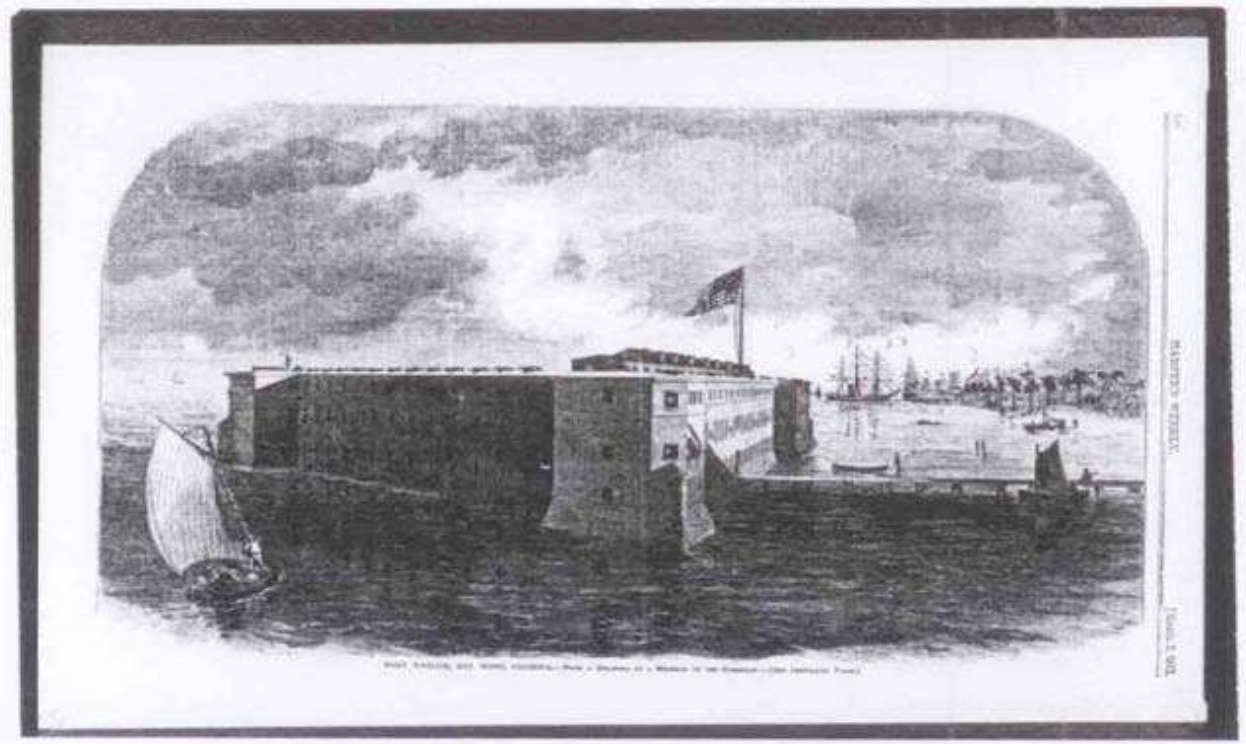

18 By the time Peirce arrived for a visit, the city was booming - it had huge warehouses stacked with wrecking goods awaiting auction, a lively wharf with many ships laden with 
products for trade, and a large Customs House, along with a diverse population of merchants and professionals.

\section{Street view of Key West, Florida}

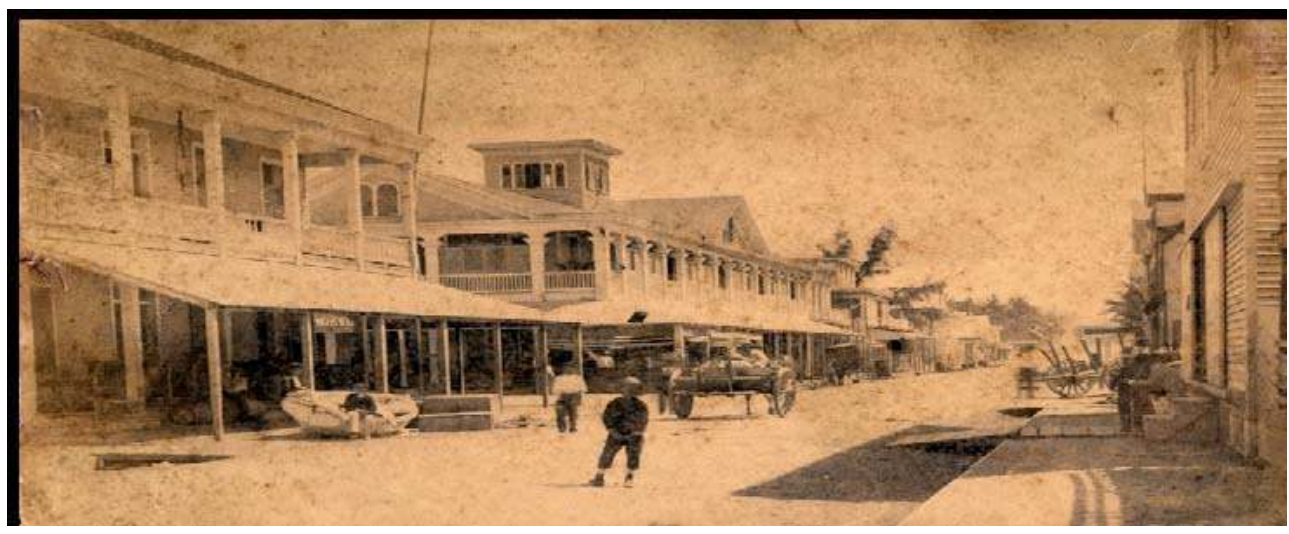

In 1886 , the year after Peirce was stationed in Key West, there was a great fire, consuming $80 \%$ of the town, so it is very difficult to find any trace of his time in Key West. There exists some correspondence from him to Hilgard, his supervisor at the U. S. Coast Survey, as well as some personal letters written by him and relatives. As a result of an examination of these, combined with additional research in Key West, Boston, and Indianapolis, I have been able to make a few interesting discoveries that add to our scanty knowledge of his time there.

In a note to Hilgard on March 1, Peirce writes

I arrived here March 1st. The others came the following Thursday. I find the Tortugas quite inaccessible...I am sorry to say that all the transportation has cost very much more than I expected. ${ }^{5}$ 
Letter from Peirce to Hilgard, 1885

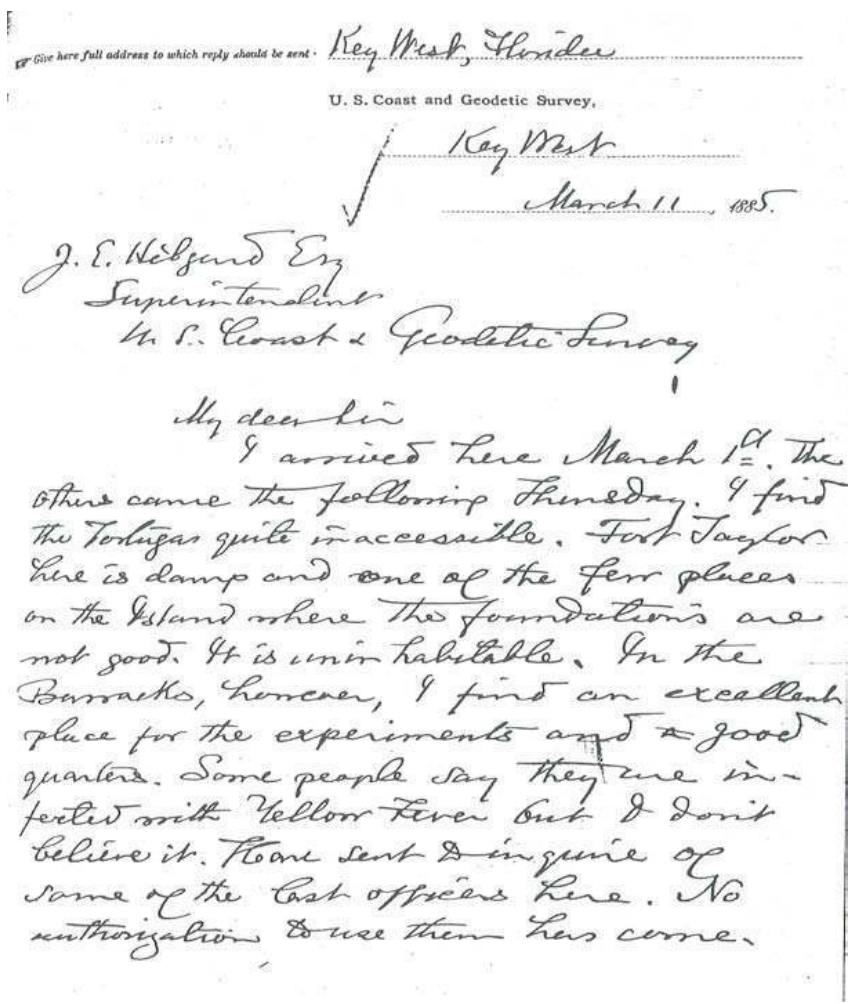

Letter from Peirce to Hilgard, 1885

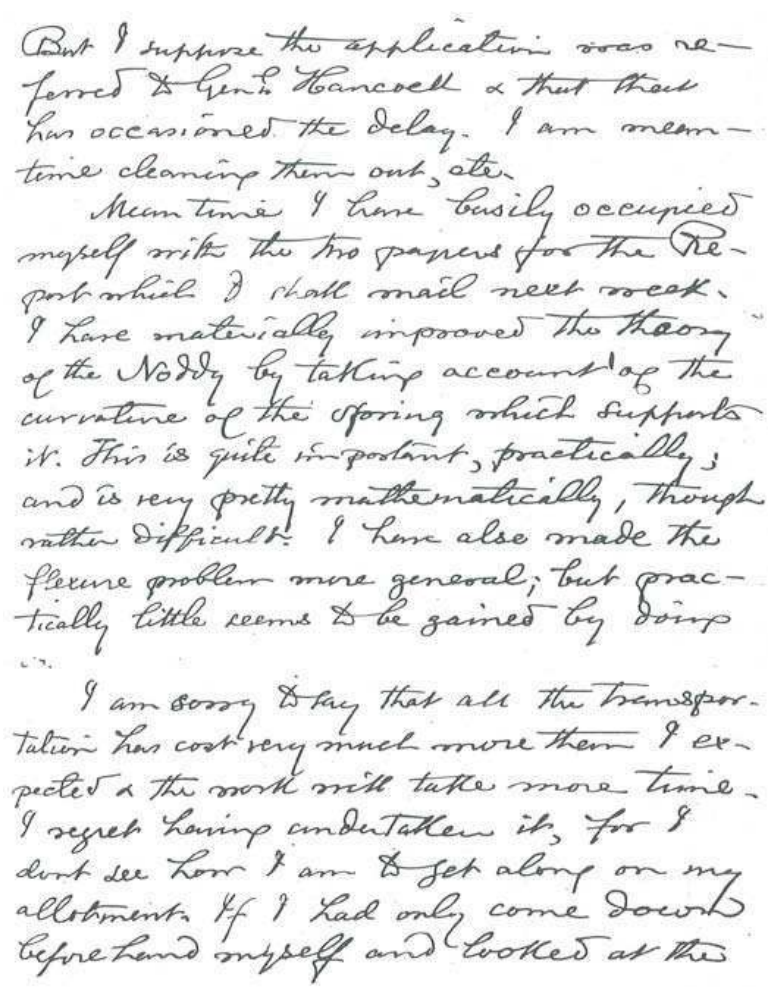


Letter from Peirce to Hilgard, 1885

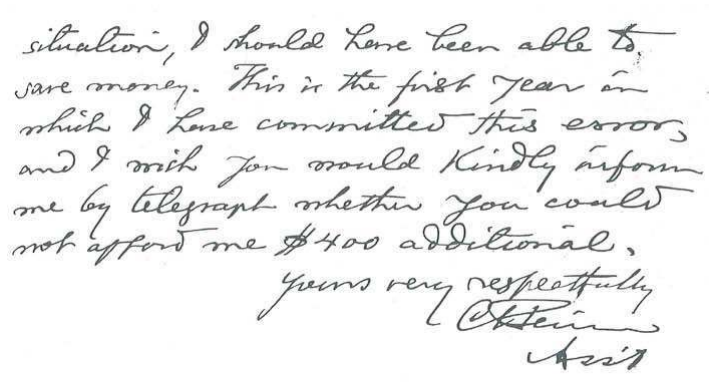

21 We do not know exactly how Peirce arrived in Key West. In a note in the "Key West" entry of the card catalogue in the Peirce Edition Project library at IUPUI, Max Fisch writes that "As of $8 / 18 / 70$ I seem to have no evidence as to how CSP traveled to and From KW". From his note to Hilgard, it is obvious Peirce did not travel via the U.S. Coast Survey, but rather traveled on a commercial ship.

By the late 1800s, the Mallory line of commercial steamers was a popular way of traveling to Key West from New York. The "Lampassas" and her sister ship, the "Alamo", launched in 1883, were two of several Mallory steamers that made the weekly trip from New York to Key West in five or six days (Baughman 1972). 
Mallory Line Steamer

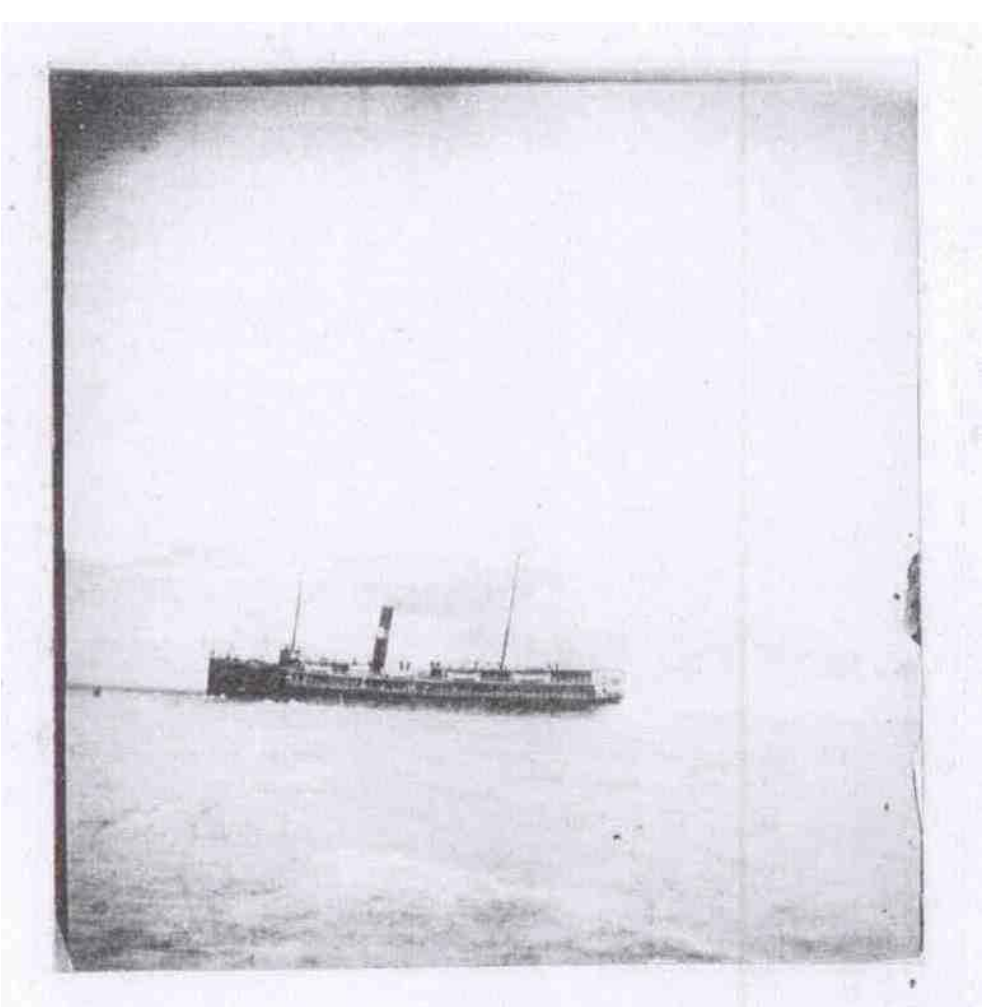

The steamer route was the New York-Galveston (Texas) route, with a stop in Key West. There were other routes to Florida, combining steamer and rail service. 


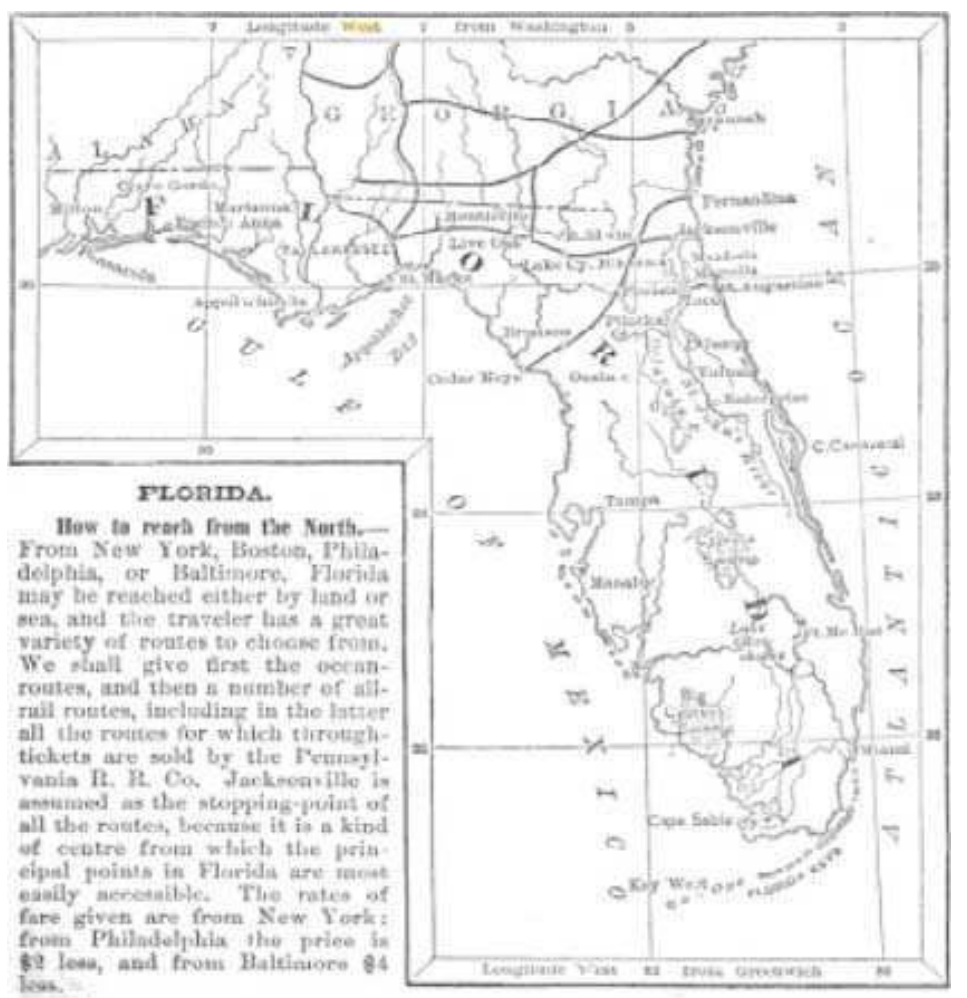

APPLETON, 1877.

I have three reasons to think that this may have been the route Peirce took: (1) he says the transportation cost more than expected (the price for the direct route was easily available); (2) he mentions the Tortugas, minor keys on the west coast of Florida, which he would have passed on this route; and (3) a few days before Peirce's arrival, Maximo Gomez, a Cuban rebel leader, had arrived in Key West, and there was a temporary interruption of the direct steamer schedule due to some commotion as a result (Stebbins: 2007). As for his return, it seems Peirce did travel directly by steamer to New York from Key West, as he states in another letter to Hilgard - "As soon as I had finished the work in Key West, I came to New York with my party. The party separated May 13 and ceased to exist May 15". We know that the party included Juliette, since Juliette usually accompanied Peirce in his travels, and a trip to Florida made sense since its temperate climate would be considered beneficial for her precarious health. Peirce's Aunt Charlotte reports:

Charley Peirce and his wife are away off at Key West on Coast Survey business weighing the earth or something. The climate of Key West is delightful. (L 676)

Peirce's mother writes before and after the trip:

Give my dear love to Juliette and tell her to take care of herself and you - I do hope the southern journey will do you both good...I am so glad you see a little improvement in Juliette's health...at least your journey was pleasant and I enjoyed greatly your account of it and your attractive fellow travelers. (L 687)

\section{And Aunt Lizzie writes:}

My dear Charley, I quite envy you being and living in such a pleasant place neither too warm nor too cold and with the delightful ocean breezes - and that ever changing, ever grand ocean constantly in view. (L 676) 
Peirce's letter to his mother while in Key West gives us a glimpse of his stay there. He says that it has "a superb climate", and that although "the town is rather stuffy", he should like to stay there for years, would not tire of it, and "would not care" if he never saw the mainland again (L 341).

\section{Letter from Peirce to his mother, 1885}

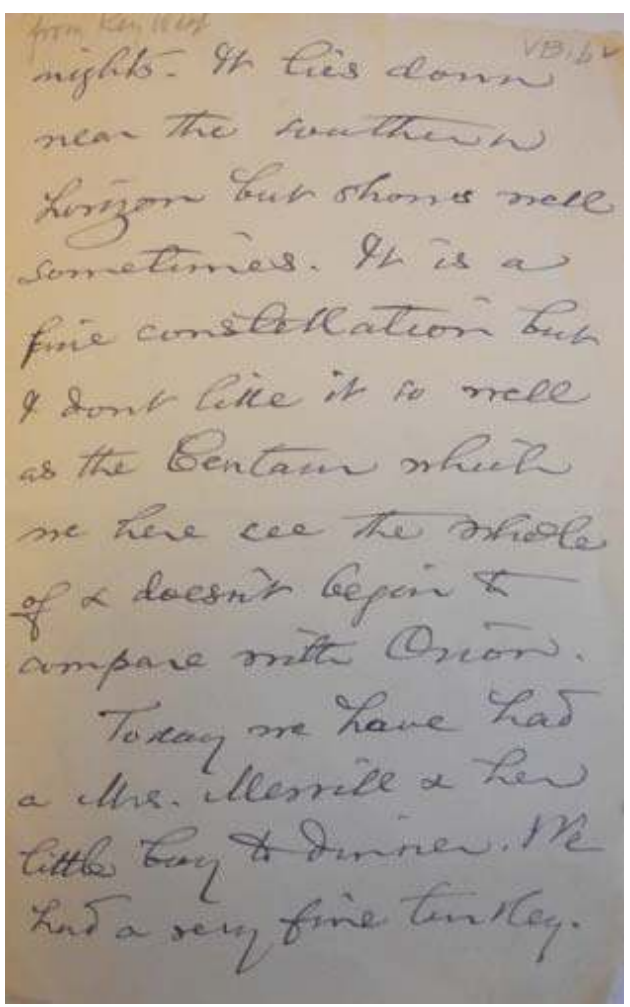


Letter from Peirce to his mother, 1885

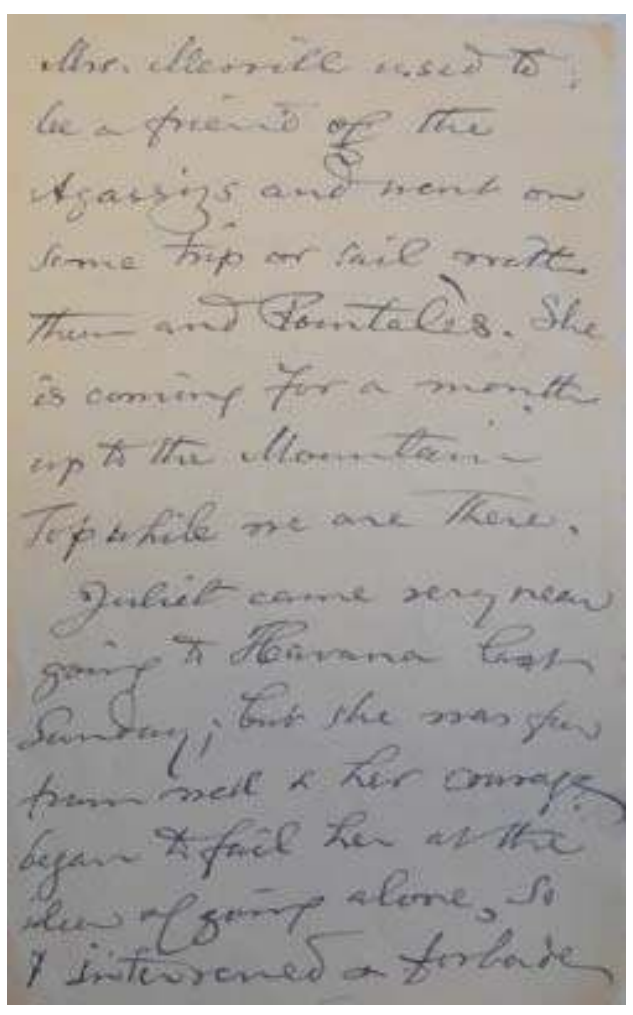

Letter from Peirce to his mother, 1885

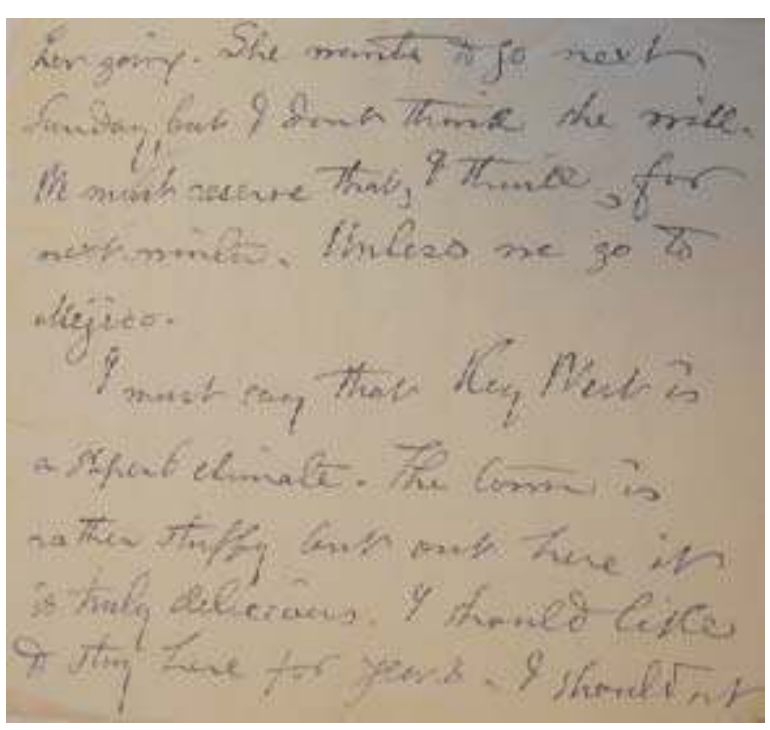


Letter from Peirce to his mother, 1885

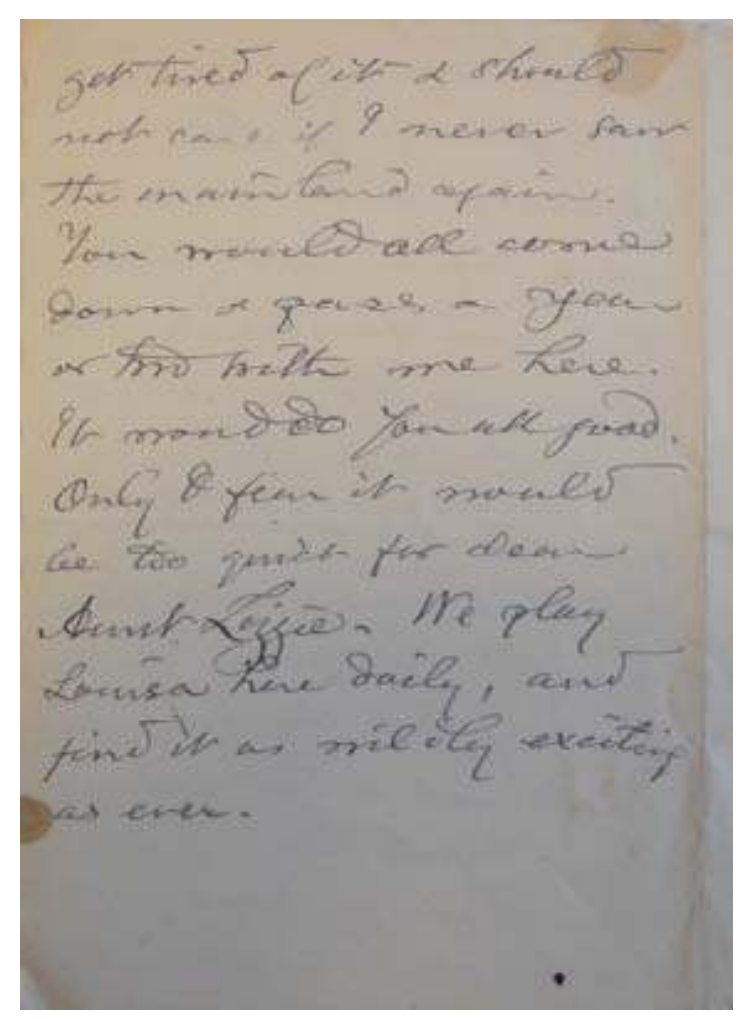

28 He describes the night sky and mentions seeing a "fine constellation" near the southern horizon, but he doesn't "like it so well as the Centaur which we here see the whole of and doesn't begin to compare with Orion". I believe Peirce is speaking of a group of stars known as the Southern Cross, which are visible only from the southern latitudes. 


\section{Southern Cross constellation}

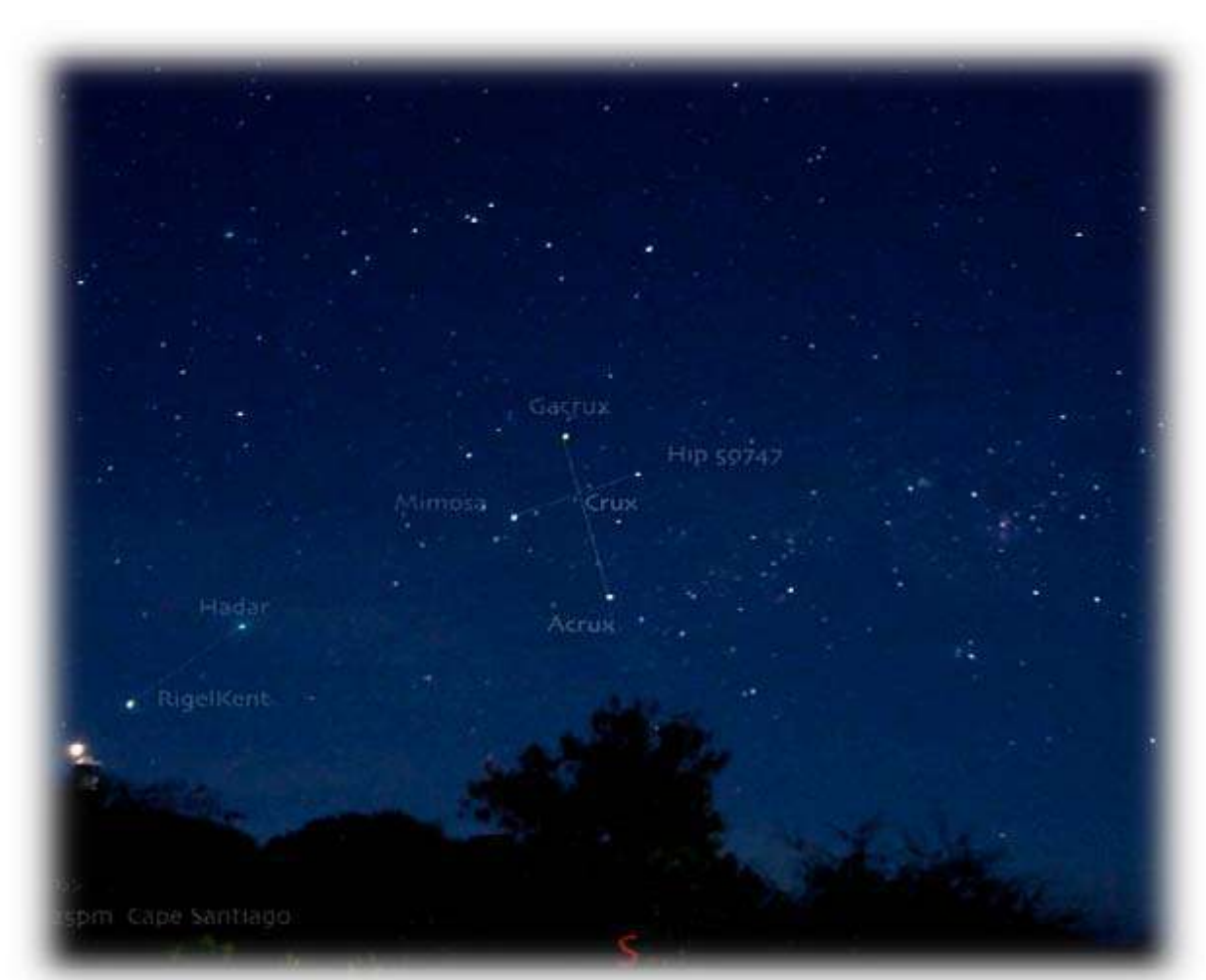

HTTP://EARTHSKY.ORg/BRIGHTEST-STARS/ONLY-SOUTHERNERS-CAN-ENJOY-HADAR/ATTACHMENT/ SOUTHERN_CROSS_HADAR_RIgEL_KENT_3-4-2013_JV_NORIEgA_580.

29 In this same letter, he mentions having "a very fine turkey" dinner with "a Mrs. Merrill and her little boy". My visit to the Monroe County Library revealed a Martha Merrill, 33 years old, of Duval Street, wife of Charles Merrill, 40 years old, hotel keeper, and mother of Russell, 9 years old listed in the 1885 Census of Key West. 


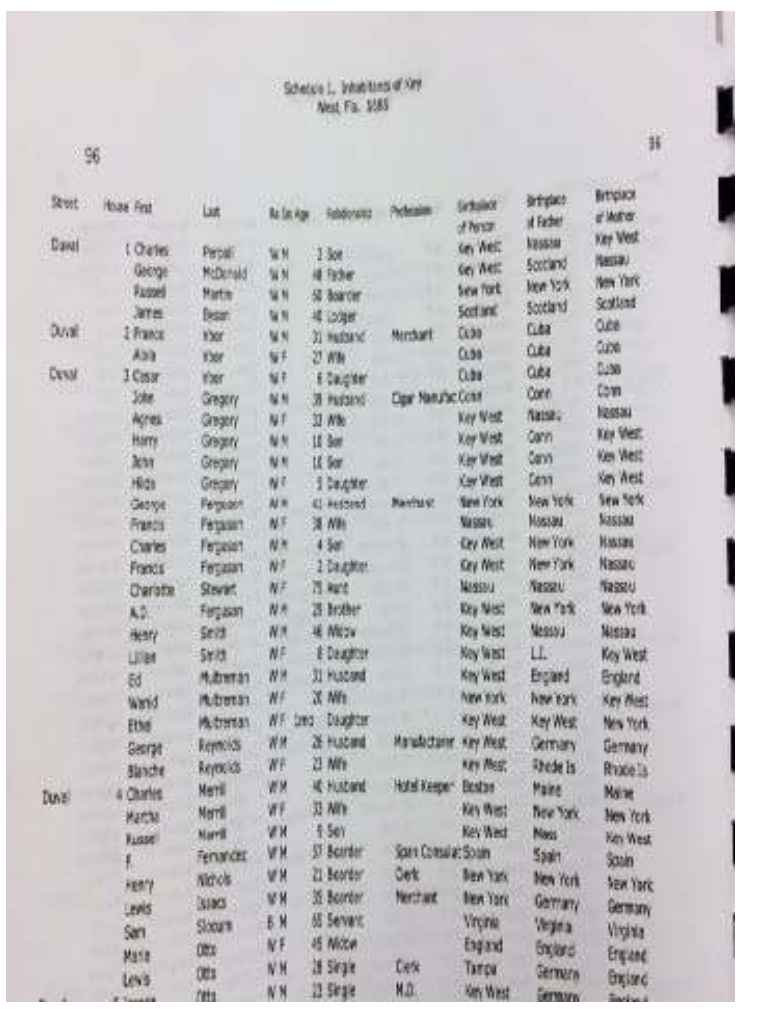

MONROE COUNTY PUBLIC LIBRARY.

Further research shows that the Merrills were the owners of Russell House, the largest and best-known hotel in Key West at the time (burned the following year during the great fire in the island). I want to claim that this is the same family that Peirce and Juliette invited to dine with them. However, I don't think the Russell House was where Peirce and Juliette stayed. In his correspondence with Hilgard, Peirce speaks of requesting permission from the Secretary of War to use the "barracks" and casemates for experiments as well as quarters. Key West, because of its prime location at the Gulf of Mexico, had several government fortifications there, including Fort Taylor, with barracks, including engineer's quarters, located in several locations in Key West. Most likely Peirce stayed at the barracks or at the engineer's quarters, which were on the outskirts of the "stuffy" town, where the ocean breeze was "truly delicious". ${ }^{6}$ 


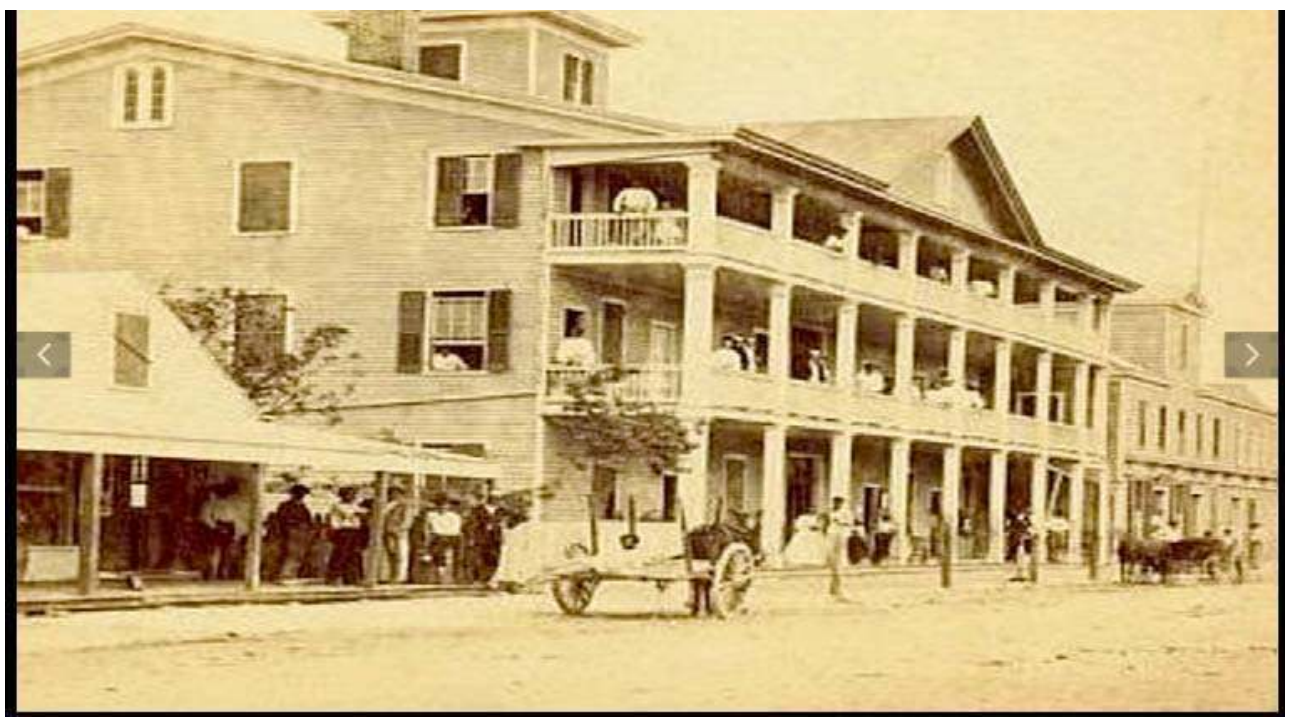

(BURNED IN 1886)

\section{Key West Barracks}

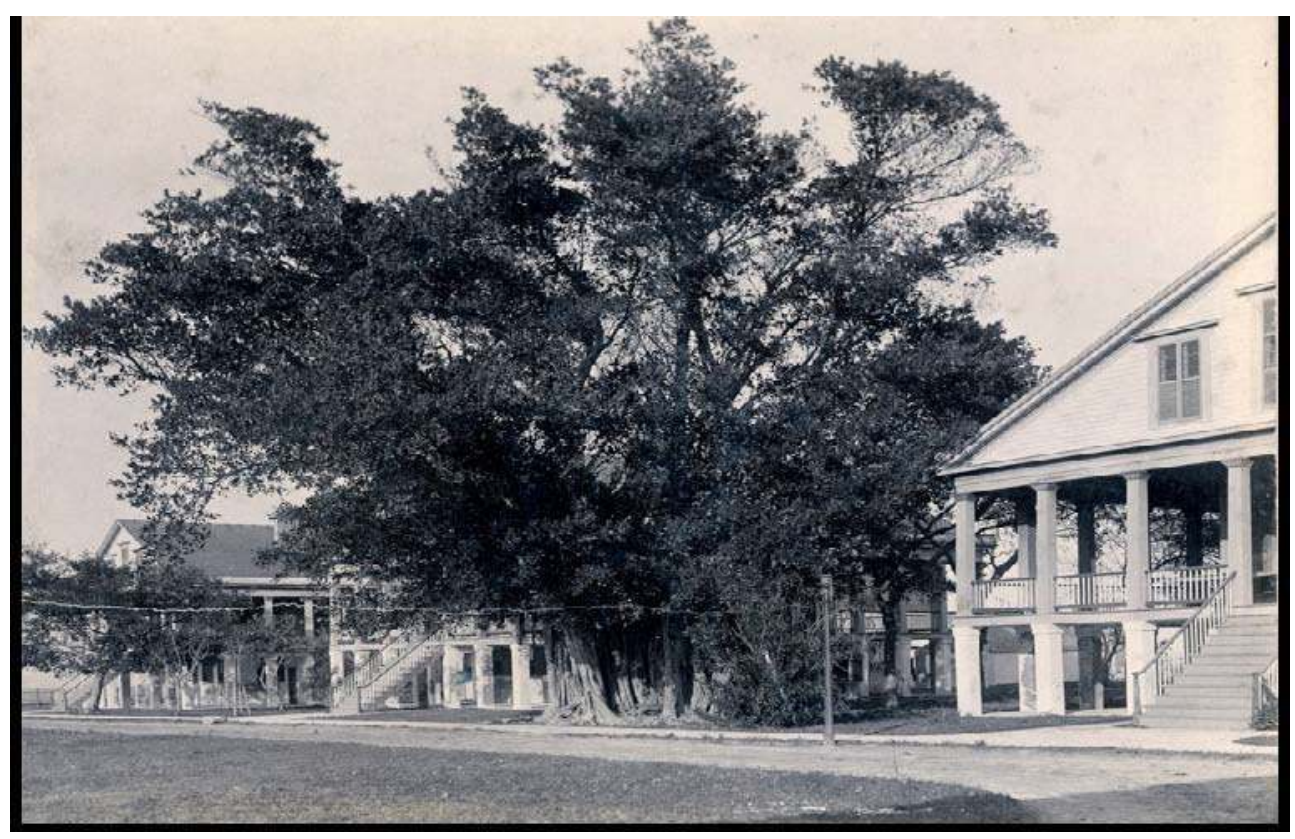


Engineer's quarters in Key West

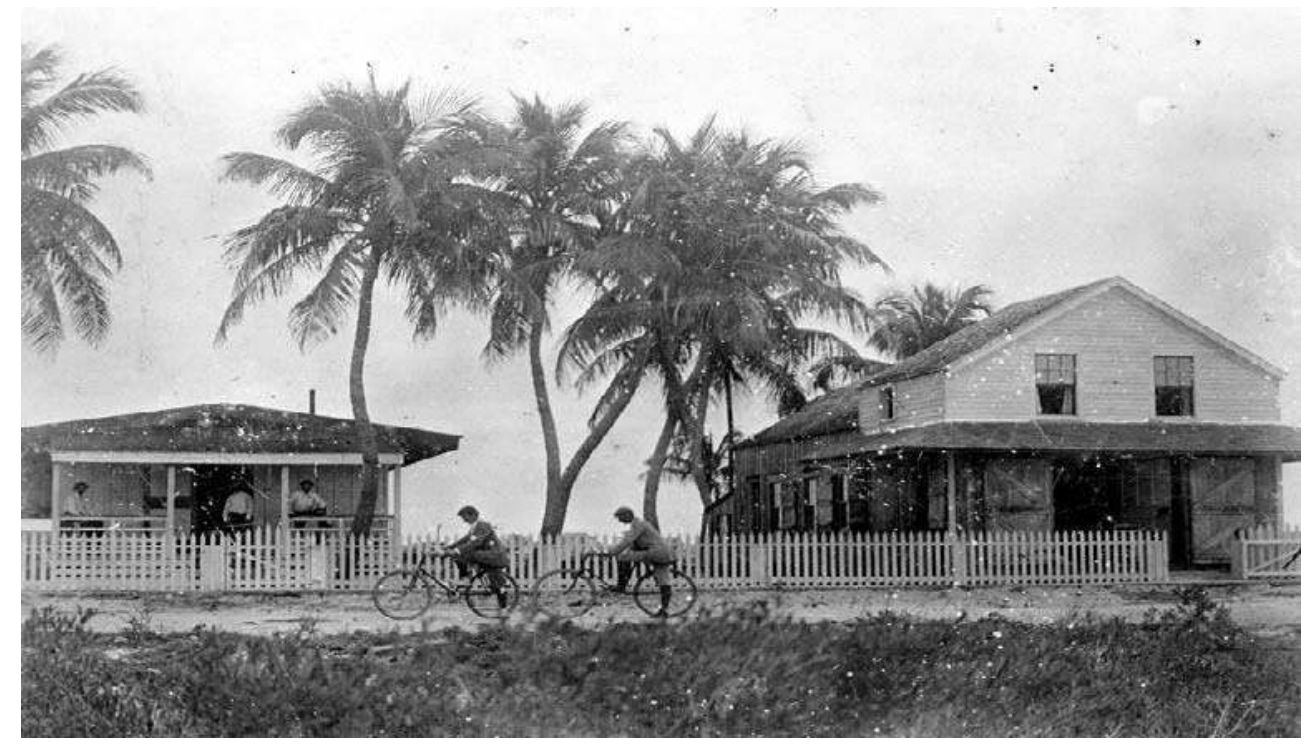

Fort Taylor casemates

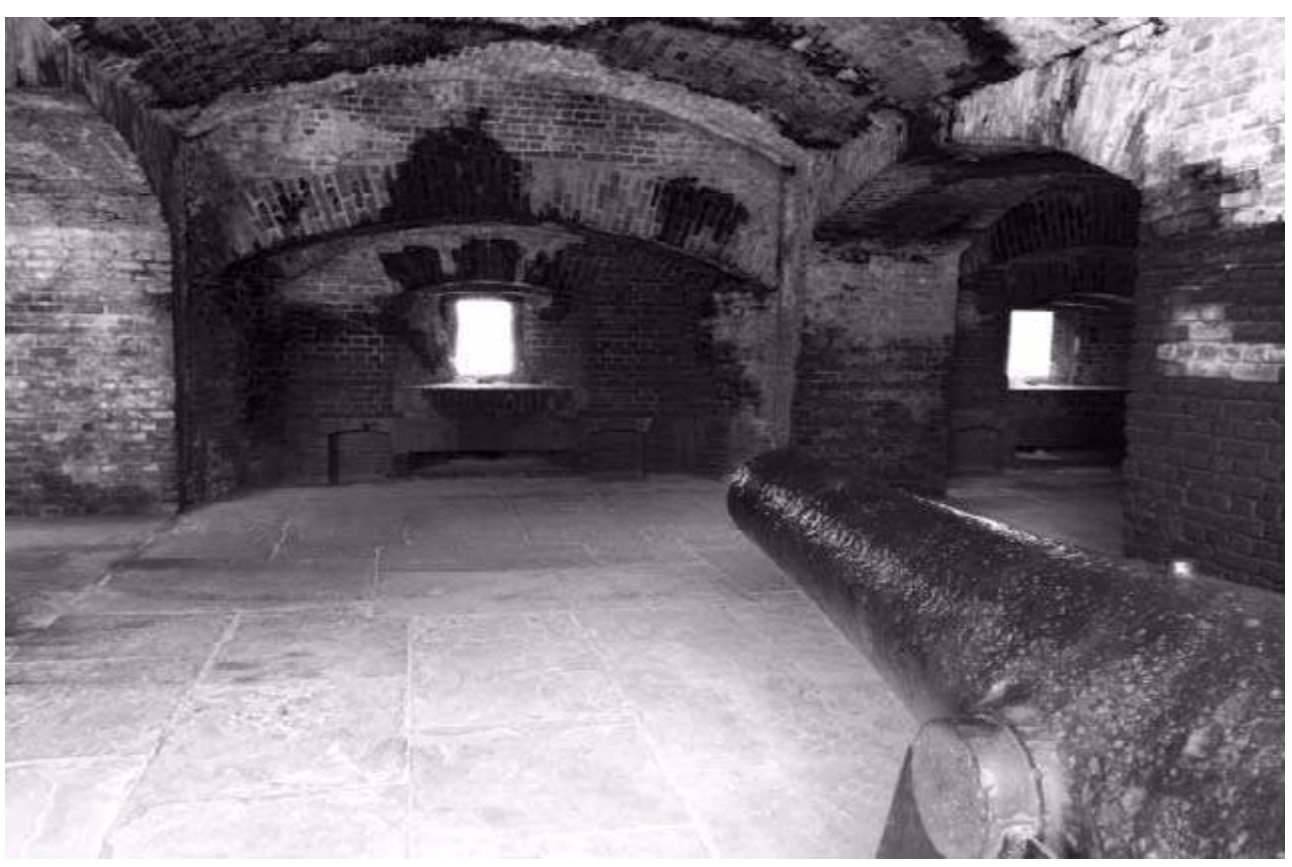

(PROBABle SITE OF PEIRCE'S gRAVITY EXPERIMENTS)

31 Peirce mentions playing "Louisa" daily while in Key West, which he finds as "wildly exciting as ever". "Louisa", I have found, was a popular board game at the time, similar to Parcheesi. 


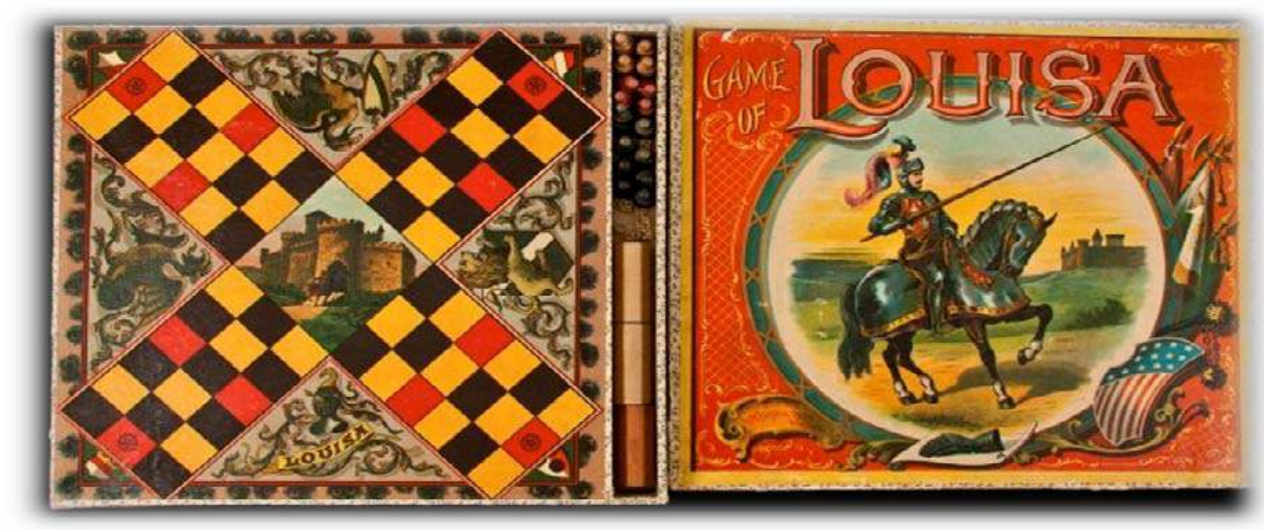

HTTP://WWW.LIVEAUCTIONEERS.COM/ITEM/11618601_RARE-BOARD-gAME-gAME-OF-LOUISA

In this same letter, Peirce mentions Juliette's never-realized trip to Havana. It was not a far-fetched idea, since at that time, there were many sailings to and from Key West and Havana for commerce as well as tourism.

\section{Havana, late 1800 s}

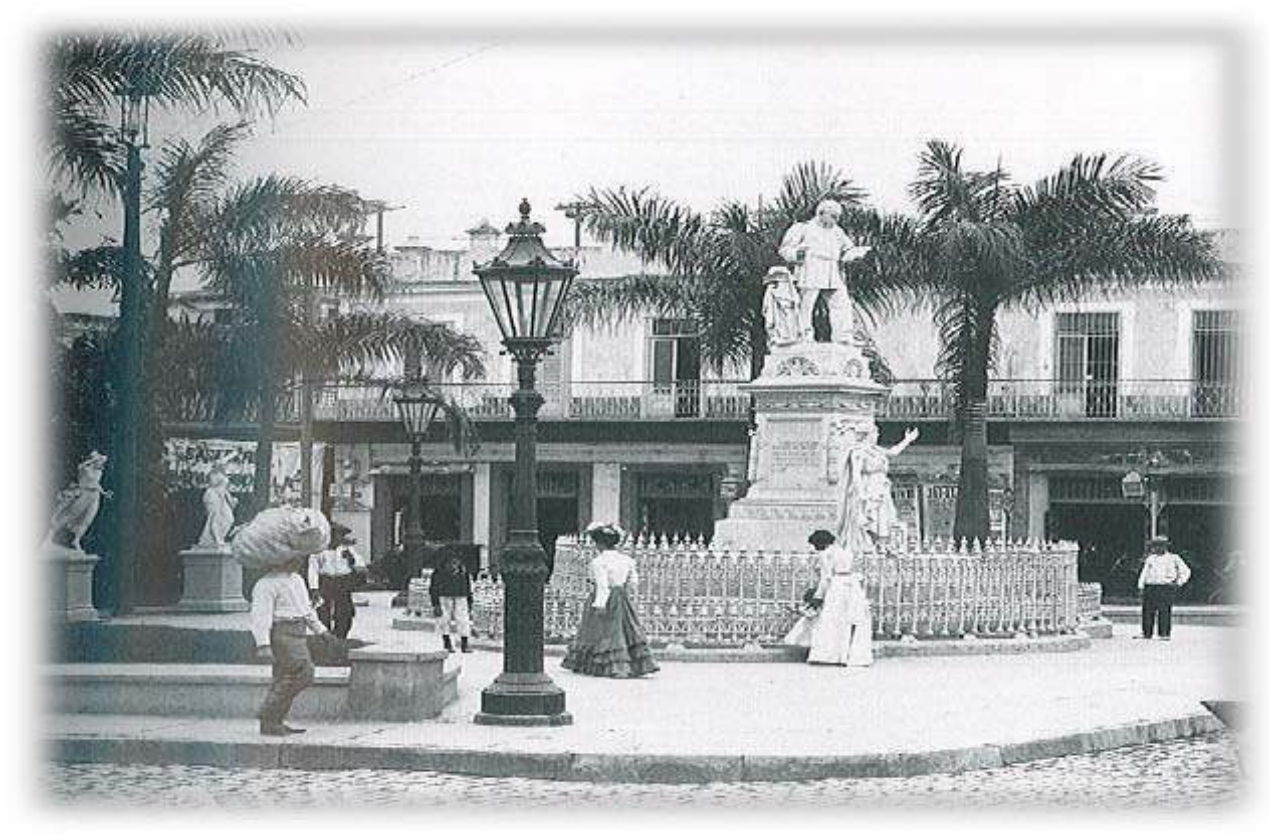

HARPER 1996.

\section{Cubans and Key West}

33 I have proposed that Peirce's favorable opinion about Cubans was likely formed during his time in Key West. By 1885, 40\% of the total population of Key West (19.000) was Cuban. The exodus of Cuban émigrés and exiles to Key West began during Cuba's Ten Years' War (1868-1878). This unsuccessful attempt to gain independence from the colonial rule of Spain resulted in widespread persecution of many Cubans who aligned with the cause. 
Thousands emigrated to New Orleans, New York, and to Key West. By the time Peirce arrived, there was a sizeable Cuban population who owned or worked in the cigar industry.

The cigar industry had come to Key West in the 1830s and next to wrecking, produced the most revenue. Even after the Ten Years' War, the exiled Cubans remained in Key West, dedicating themselves and donating their earnings to support the liberation of Cuba from Spain. With a population of almost 7.000 Cubans on the island, Key West had become a "Little Havana" in the 1880s, recognized as the center of the Cuban insurgency. It had its own newspaper, El Yara, whose founder and owner, J. D. Poyo, printed the latest news of fighting in Cuba. Ironically, less than a hundred years later, there would be another great exodus of Cubans to the U.S. (and to rest of the world) as a result of the Castro revolution in 1959. This time, "Little Havana" would be located a few hundred miles north of Key West, in Miami, Florida. But I'm getting ahead of my story.

Peirce most likely met several well-to-do Cubans residing in Key West, including Eduardo Hidalgo Gato, a wealthy Cuban cigar factory owner who established Gatoville, a successful industrial community, which encompassed housing, parks, and schools adjacent to the cigar factory.

\section{Eduardo Hidalgo Gato, founder of Gatoville}

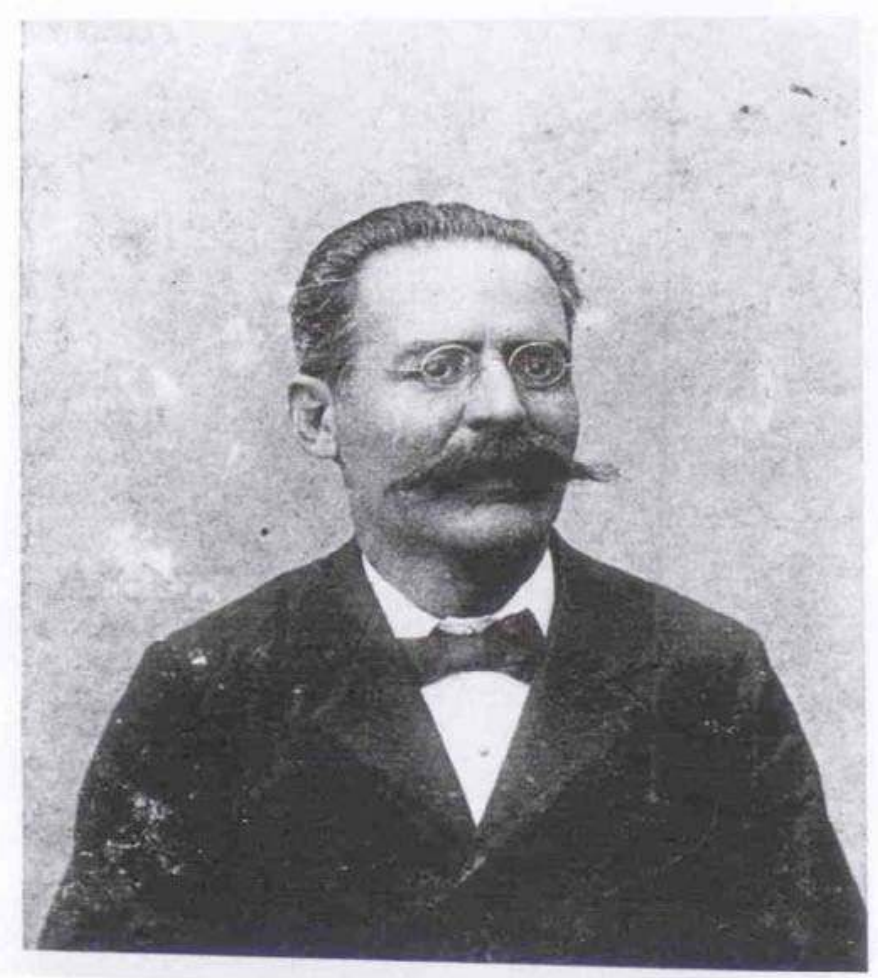

36 I think Gatoville and/or other cigar factories is what reminded Peirce of the famed Lynn shoemaking center in Massachusetts which he mentions in his letter to Cabot Lodge. He obviously was impressed with the Cuban cigar-making tradition of having a reader in the cigar factories who would read literature (and the latest revolutionary news, no doubt) to the cigar workers.

37 Every morning a man, highered by the cigar makers, mounted a pulpit in the factory \& read to them all day. The only crime of violence that winter was by an American (L 341). 
The lector in a Cuban cigar factory

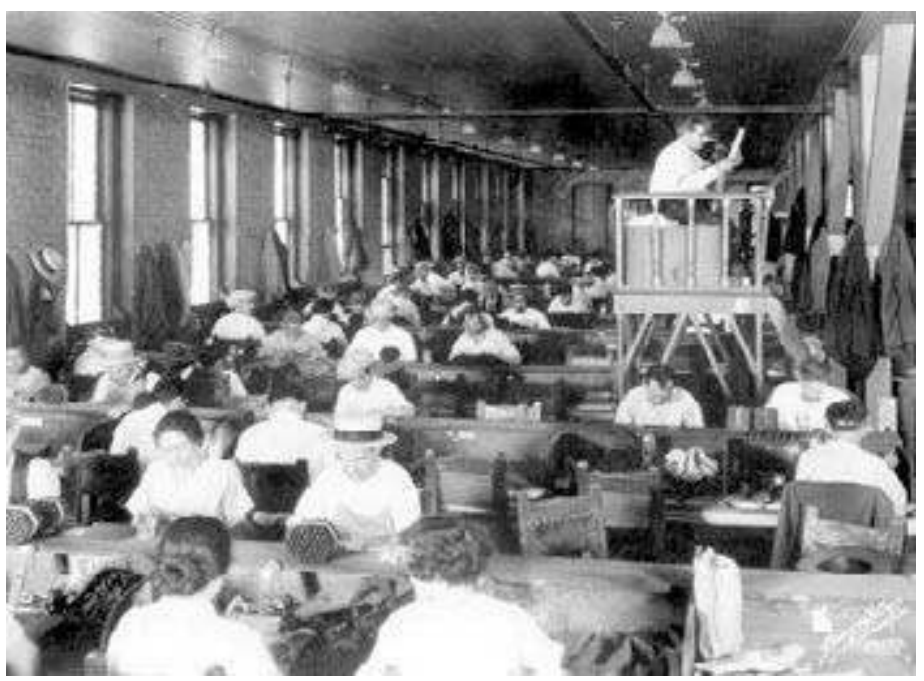

The great fire of 1886, however, ended the cigar industry in Key West, a considerable source of financial support for the Cuban independence movement; some cigar owners re-established their business in Tampa. The fire started in the San Carlos Institute, a school and social gathering place for Cubans, and quickly spread to the rest of the island. It was rumored that the fire was started by the Spanish consul to stop the subsidies by the Cubans for the insurrection against Spain.

\section{The San Carlos Institute (rebuilt after the $\mathbf{1 8 8 6}$ fire)}

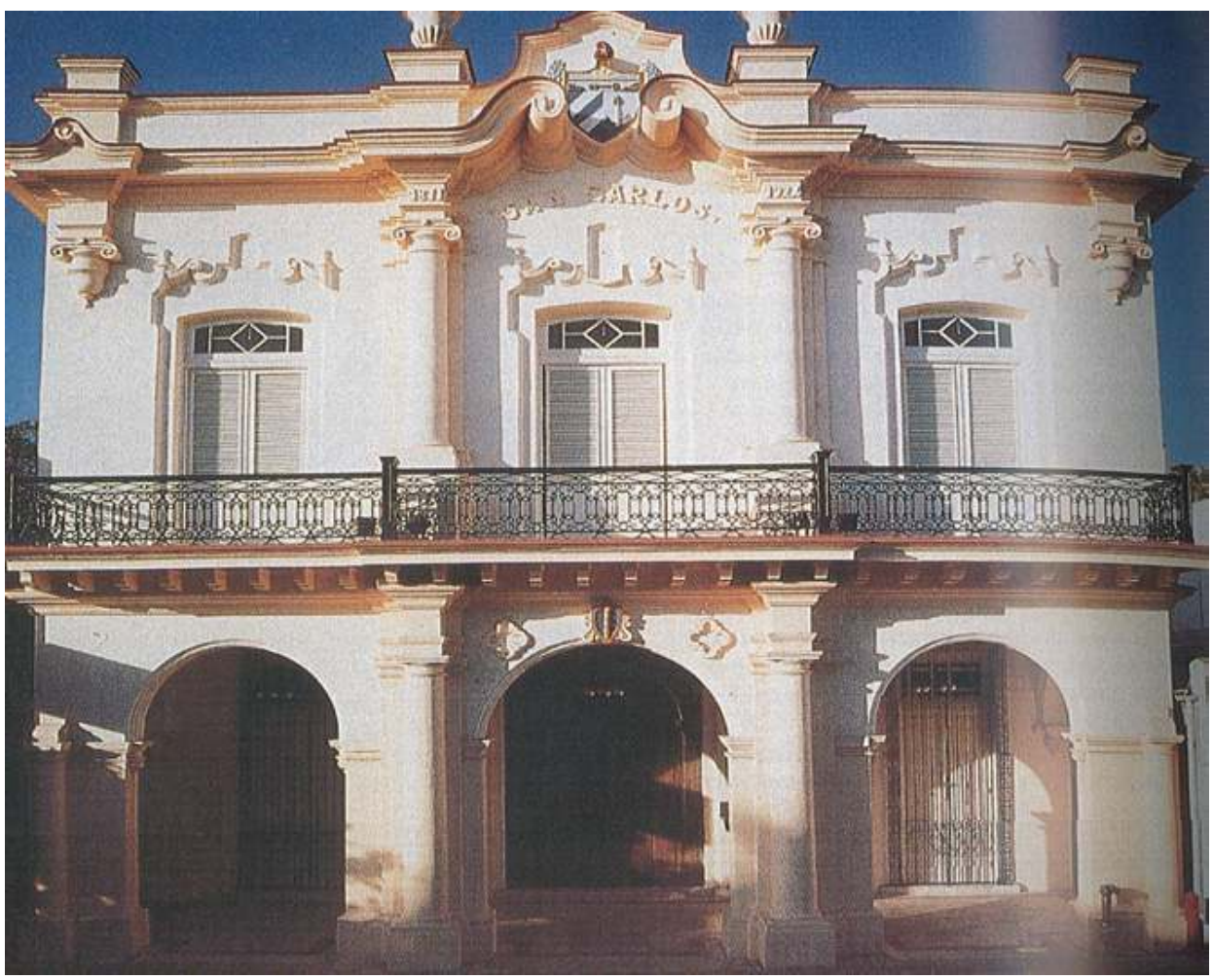

HARPER 1996. 


\section{Pragmatism and Cuba Then} practical usefulness", which explains the purpose of thought guiding action. In this way, "the effect of an idea is more important than its origin". Armas' point, which he will argue throughout the book, is that it is easier to manipulate people's behavior if truth is made to be relative to function, practicality, action. Traditional values, grand ideas, longheld beliefs, are to be submitted to a test; if they are not useful, they are to be discarded, regardless of origin. Armas then uses this interpretation of Dewey to try to say that it is "the source for the worst conservative policies of the U.S. associated with a lack of morals in its political behavior in the international arena" (Armas 2004: 23).

A copy of El Pragmatismo en Cuba, by Antonio Armas Vasquez, published in Havana in 2004, was the book that Michael Eldridge handed to me several years ago in Virginia. Elsewhere I have discussed the contents of the book, including a panel presentation at the Texas A\&M First International Conference on Pragmatism in the Hispanic World with the book's author (Mayorga 2010). I will briefly mention some points here.

Armas' theory is that crucial events in Cuba's history between 1895 (the official commencement of the war of independence from Spain) to 1959 (the official takeover by the Castro rebellion), are directly related to the promulgation of pragmatism as a philosophy in Cuba by the United States.

Armas argues, the United States sought to exert covertly its complete control over the young nation in order to fulfill its own capitalist and imperialist agenda.

controlled by the United States, sometimes outwardly, sometimes in more subtle ways, by a continuous and constant bombardment of ideas, techniques, organizations, social projects, cultural manifestations, and policies (both scientific and economic), with the intention of restructuring the base of a new social system and of consolidating a new culture based on the Anglo-Saxon one. Pragmatism as a philosophy provided the methodology for this, Armas argues, since its strides in psychology, education, and sociology served to become "a notorious influence" in integrating better the aspirations of the U.S. in spreading its system of ideas.

Before devoting the rest of the book to historical examples of how Cubans were adversely affected by pragmatism, Armas attempts an explanation of pragmatist theory. He rightly identifies pragmatism's origins with Charles Peirce and William James. However, Peirce is mentioned only in passing; Armas has more to say about other pragmatists, especially Dewey.

According to Armas, Dewey considers that "the proof of the truth of a proposition is its Furthermore, Dewey's interest in reforming the theory and practice of education is interpreted by Armas as providing the methodology for achieving this aim. This instrumentalism and functionalism directly influenced not only pedagogy, but the sociology and psychology of the time, Armas claims. Experimental psychology, for example, "manifested itself with great force directed towards the conduct of the student and its control".

The link between pragmatism, politics, psychology and sociology can be seen, according to Armas, in valuing personal success and the value of individual work, which go hand in 
hand "with the capitalist production process" (Armas 2004: 20), and provided the opportunity for the U.S. to control the destiny of the new nation.

I have argued that Armas' interpretation of Cuba's history in light of pragmatism, is at best imaginative, but inaccurate and misrepresentative at worst. His interpretation of the philosophy of pragmatism, whether Dewey's or others', fares no better. For all its historical and interpretive inaccuracies colored by politics, however, Armas' book correctly points to the fact that pragmatism was widely known and discussed among the Cuban intelligentsia prior to 1959. Alfredo Aguayo, the renowned Cuban educator, translated Dewey's works and supported his pedagogical reforms (Armas provides this as an instance of an "apologia" of American democracy). Enrique Jose Varona, another pioneer in educational reforms in the early years of the twentieth century, argued for psychology, logic, and ethics as part of the pre-university curriculum, and substituted English and French for the classic Latin and Greek.

Also at the pre-university and university levels, the study of James' philosophy, as well as that of other pragmatists, was included in the curriculum by Cuban philosophers; a notable case is Roberto Agramonte, who wrote extensively on pragmatism in the 1940s.

The Castro revolution and its adoption of Marxism in the 1960s completely reformed the curriculum to reflect Communist ideology. One of its first initiatives was to close and restructure the Philosophy Department at the University of Havana; only Marxist philosophy was allowed as part of the curriculum. In the last few years, due mostly to limited (clandestine) access to the Internet, and relaxed travel sanctions for cultural exchanges (such as the one Michael Eldridge participated in), there is evidence that some of pragmatism's ideas, including Peirce's, especially his semiotics, are beginning to be studied.

\section{Pragmatism and Cuba Today}

Can pragmatism be of any utility to the many problems Cuba faces today? This is a question that a Deweyan pragmatist like Michael Eldridge might pose. Among Cuba's many problems is a failed political and economic system where dissenting views are considered dangerous and highly discouraged (in very forceful ways). One possible answer to this question might be found in Robert Talisse's A Pragmatist Philosophy of Democracy (he does not deal with this issue there, however).

51 Although, as is well known, Dewey wrote extensively on democracy (while Peirce did not), Talisse tries to reconstruct a pragmatist view of democracy based on Peirce's scientific method of fixing belief, as opposed to basing it on Dewey's political theory.

Talisse finds that Dewey's substantive conception of democracy is too "normatively thick", and comprehensive, combining too much metaphysics, epistemology, and ethics to the extent that it cannot accommodate "reasonable pluralism", (that is, the claim that disagreements over certain questions are permanently and unavoidably irresolvable) resulting in a pragmatism that is oppressive to some, and therefore nonviable in practice. (Armas would probably not disagree with this claim). Talisse proposes instead a "Peircean" epistemic account of democracy that is not burdened with metaphysics or ethics or other philosophical commitments beyond the pragmatic maxim and hence can accommodate reasonable realism, thereby avoiding Dewey's mistakes. 

true is to say that it will forever withstand the challenges of reason, evidence, and argument; therefore we cannot deliberately and self-consciously inquire in any way but the scientific way. From this we can conclude that only the scientific believer actually pursues truth. Responsible "epistemic agency" is achieved only by scientific believers, since only they have the character of self-aware and self-controlled inquirers. "Epistemic character", "epistemic responsibility" and "proper epistemic practice" are then proposed by Talisse as the fundamental ideals for a democracy. These are not tied to a specific social-cultural system, so that they can accommodate reasonable pluralism and hence do not prescribe the oppression of reasonable dissenters. Yet these ideals provide a commitment to the idea that even the deepest disagreements should be ruled by a certain set of norms (in this case, epistemic ones).

Elsewhere, I have quibbled with several of Talisse's claims, including the assertion that Peirce has no (or less) metaphysical and ethical commitments than Dewey; I will not go over them here (Mayorga 2009). However, as described, I can see how such a guide for policy-making based just on trying to get to the truth of the matter, would be extremely valuable in a system such as Cuba's, where, if a true dialogue is ever started, will have to include all voices of the population, the aging revolutionaries, as well as the old and the new generations of political dissenters.

The problem in a nutshell with Talisse's substantive epistemic Peircean account in this case, though, is that it fails to see the close connection between the normative and the epistemic. Peirce identified a kind of reasoning which could be considered an "epistemological vice" - sham reasoning. Sham reasoners are more concerned with proving a preconceived conviction than finding the truth. Susan Haack has identified a second kind of "epistemological vice" - fake reasoning (Haack 2008: 10). Fake reasoners are mostly concerned with advancing themselves, and will sacrifice truth when convenient. Neither sham nor fake reasoners care to find out how things really are. For Talisse's proposal to work as a useful guide in the creation or improvement of a political system, truth, the aim of the scientific believer, needs to be valued and respected. Unfortunately, the desire for power and control, combined with sham and fake inquiry, often take precedence over the search for truth.

\section{BIBLIOGRAPHY}

APPLETON D., (1877), Appleton's Illustrated Guide of Winter Resorts for Tourists and Invalids, New York:

D. Appleton and Company.

ARMAS V. A., (2004), El Pragmatismo en Cuba, Habana: Sociedad Cubana de Investigaciones

Filosoficas.

BAUGHMAN J., (1972), The Mallorys of Mystic, Middletown: Wesleyan University Press.

BRENT J., (1993), C. S. Peirce A Life, Bloomington: Indiana University Press.

European Journal of Pragmatism and American Philosophy, VI-2 | 2014 
HAACK S., (2008), Putting Philosophy to Work, Amherst: Prometheus Books.

HARPER P., (1996), “Cuba Connections: Key West-Tampa-Miami, 1870-1945”, The Journal of

Decorative and Propaganda Arts, 22.

LARRUA-GUEDES S., (2010), Historia de la Florida Colonial Hispana Tomo I, Coral Gables: Espana Florida Foundation.

MAYORgA R., (2009), “On Talisse's Peirceanist Theory”, Transactions of the Charles S. Peirce Society,

45,1 .

MAYORGA R, (2010), "El Pragmatismo en Cuba by Antonio Armas Vázquez", Transactions of the

Charles S. Peirce Society, 46, 2.

Nubiola J., (1998), “C. S. Peirce and the Hispanic Philosophy of the Twentieth Century”,

Transactions of the Charles S. Peirce Society, 24, 1, 31-49.

NUbiola J., and Fernando zalamea (2006), Peirce y el mundo hispanico, Pamplona, Ediciones

Universidad de Navarra.

PEIRCE C. S., (1982), Writings of C. S. Peirce: A Chronological Edition, 7 vols. published, ed. by M. Fisch et al., Bloomington, Indiana University Press.

ROBIN R., (1967), Annotated Catalogue of the Papers of Charles S. Peirce, Boston, University of Massachusetts Press.

schoultz L., (2009), That Infernal Little Cuban Republic: The United States and the Cuban Revolution, Chapel Hill, The University of North Carolina Press.

STEBBINS C., (2007), City of Intrigue, Nest of Revolution, Gainesville: University Press of South Florida.

TALISSE R. (2007), A Pragmatist Philosophy of Democracy, New York, Routledge Press.

\section{NOTES}

2. My thanks to Jaime Nubiola (University of Navarre), Andre de Tienne (Peirce Edition Project, IUPUI); Tom Hambright (Monroe County Library, Key West), and Katia Dabdoub Hechema for their continued assistance with Key West history.

3. The Teller Amendment prohibited annexation of Cuba; however the Platt Amendment (eliminated from the Cuban constitution in 1940) gave the U.S. the right to intervene militarily.

4. It's also possible he came into contact with Cubans in New York; Jose Marti, for example, a leading figure in the Cuban independence movement, was exiled and lived in New York for many years. Marti gave many public lectures in support of the Cuban cause.

5. Found under CSP-JEH in the Max Fisch catalogue at the PEP, IUPUI.

6. Apparently, there were several barracks located in different parts. There were some at Fort Taylor, but there were other "Key West Barracks" located on the other side of the island. There are telegrams where Peirce writes that the authorization to use the Key West Barracks was erroneously sent to the sergeant at Fort Taylor, so Peirce may have stayed at the Fort Taylor barracks (though he says they were "inhospitable") for some time before the authorization for the other barracks arrived. 


\section{ABSTRACTS}

Although Peirce, as far as we know, did not visit Cuba (or any other Latin American country), it is argued that his favorable impression and interesting remarks about the Cuban character are likely the result of the time he spent in Key West, Florida, while conducting gravity experiments for the Coast Survey. This paper tries to provide a snapshot of this little-known period in Peirce's life, the time of Cuba's struggle for independence from Spain, and ends with brief comments on pragmatism and Cuba, past and present. 